\title{
COMPARATIVE STUDY OF TOTAL LEUCOCYTE COUNT AND GRANULOCYTE, AGRANULOCYTE COUNT IN DIFFERENT AGE GROUPS DURING MENSTRUAL CYCLE
}

\author{
Sumpi Rosemary Anal1, Kanmi Ningshen², Laishram Leimahanbi Chanu ${ }^{3}$ \\ ${ }^{1}$ Assistant Professor, Department of Physiology, Jawaharlal Nehru Institute of Medical Sciences (JNIMS), Imphal, Manipur, India. \\ ${ }^{2}$ Demonstrator, Department of Physiology, Jawaharlal Nehru Institute of Medical Sciences (JNIMS), Imphal, Manipur, India. \\ ${ }^{3}$ Demonstrator, Department of Physiology, Jawaharlal Nehru Institute of Medical Sciences (JNIMS), Imphal, Manipur, India.
}

\section{ABSTRACT}

\section{BACKGROUND}

Menstrual cycle is the cyclical phenomenon characterized by periodic vaginal bleeding. It influences all the system of the body. Menstruation occurs cyclically at intervals of 21-35 days. Uterine cycle includes menstruation, proliferative and secretory phases. It is due to invisible interplay of different levels of hormones mainly through hypothalamo-pituitary-ovarian-axis. The physiological levels of oestrogen and progesterone influence the leucocyte count. Thus, change in the count might occur when the hormonal balance changes during menstrual cycle and most commonly the organs in the body remain unaffected by this hormonal imbalance. We wanted to study the age-related variations in total leucocyte, granulocyte and agranulocyte count during different phases of menstrual cycle in $1^{\text {st }}$ professional MBBS students at, Jawaharlal Nehru Institute of Medical sciences (JNIMS), Imphal, Manipur.

\section{METHODS}

It is a longitudinal study. 50 healthy female medical students in the age group of $18-25$ yrs. with regular cycles of $28 \pm 2$ days duration participated in the study. Students with irregular cycles, gynaecological disorders like endometriosis, fibroid, irregular bleeding, history of prolonged drug intake and history of fever were excluded from the study. Study protocol was explained to the students and informed consent was obtained from each of the students. Institutional ethical committee clearance was obtained. First sample was collected within 48 hours of onset of menstruation, second sample during $8^{\text {th }}-10^{\text {th }}$ day of menstrual cycle. Third sample was taken during $22^{\text {nd }}-24^{\text {th }}$ day of menstrual cycle. All the subjects were followed up during a single cycle. Samples were taken in the morning between 9 am-10 am to avoid diurnal variation. Total leucocyte count was determined with Improved Neubauer's chamber using Turk's fluid. Granulocyte- and agranulocyte-count was determined using Leishman's stain under compound microscope. Total leukocyte count and granulocyte and agranulocyte cells were examined during a single cycle. Data collected was statistically analysed.

\section{RESULTS}

There was increase in total leukocyte count in the 23-25 years age group in different phases of the menstrual cycle as compared to other age groups but was not statistically significant and increased granulocyte count was seen in both the aged groups (17-19), (23-25) years in all phases of menstrual cycle was statistically significant. Agranulocyte count was increased in 23-25 years age group in all phases but was not statistically significant.

\section{CONCLUSIONS}

This study was an attempt to determine the normal variations in the total leucocyte count and granulocyte-, agranulocyte-count in different aged groups during the different phases of the menstrual cycle which may help in understanding various autoimmune diseases (rheumatoid arthritis, systemic lupus erythematosus, autoimmune thyroid disease, multiple sclerosis etc.) occurring in reproductive age groups.

HOW TO CITE THIS ARTICLE: Anal SR, Ningshen K, Chanu LL. Comparative study of total leucocyte count and granulocyte, agranulocyte count in different age groups during menstrual cycle. J. Evolution Med. Dent. Sci. 2019;8(20):1628-1631, DOI: $10.14260 /$ jemds/2019/360

\section{BACKGROUND}

The term 'menstruation' is derived from the Latin word 'mensis' meaning Lunar month of 28 days.[1] Menstruation is defined as "periodic and cyclical shedding of endometrium accompanied by loss of blood" during the reproductive age. [2]

'Financial or Other Competing Interest': None.

Submission 30-03-2019, Peer Review 04-05-2019,

Acceptance 11-05-2019, Published 20-05-2019.

Corresponding Author:

Dr. Kanmi Ningshen,

Block-B, Nagaram,

Khuman Lampak Road,

Imphal East-795010,

Manipur, India.

E-mail: kanov24@gmail.com

DOI: $10.14260 /$ jemds $/ 2019 / 360$
Normally, the first menstruation occurs between 11-15 years of age with a mean of 13 years. Uterine cycle includes menstrual, proliferative, secretory phases. Menstruation occurs cyclically at intervals of 21-35 days. ${ }^{[3]}$ It is due to invisible interplay of different levels of hormones mainly through hypothalamo-pituitary-ovarian-axis. The hypothalamus secretes regularly peptides i.e. Gonadotropin releasing hormone $(\mathrm{GnRH})$. This peptide reaches the anterior pituitary gland via hypothalamic 'pituitary portal system to stimulate release of mainly LH and to a lesser extent, FSH from specialized cells referred to as gonadotropes or beta cells. The release of GnRH by hypothalamus is pulsatile, with pulses occurring every 90 mins. This leads to pulsatile release of FSH and LH. Frequency of GnRH bursts is increased by oestrogen and decreased by progesterone. 


\begin{tabular}{|c|c|c|c|c|c|}
\hline 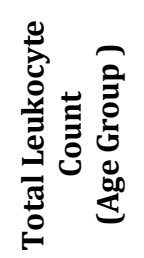 & 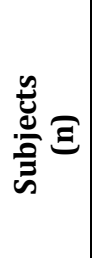 & 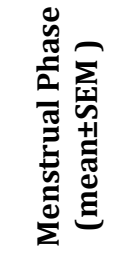 & 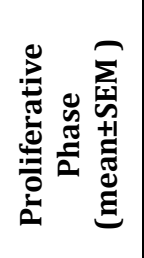 & 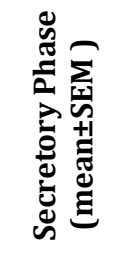 & $\begin{array}{l}\frac{0}{\Xi} \\
\frac{\pi}{d} \\
\vdots\end{array}$ \\
\hline $17-19$ yrs. & 26 & $\begin{array}{l}9196.1 \pm \\
376.4\end{array}$ & $\begin{array}{l}8804.3 \pm \\
306.1\end{array}$ & $\begin{array}{l}9650.5 \pm \\
285.5\end{array}$ & 0.48 \\
\hline $20-22$ yrs. & 14 & $\begin{array}{c}8779.2 \pm \\
465.1 \\
\end{array}$ & $\begin{array}{c}8950.6 \pm \\
410.4 \\
\end{array}$ & $\begin{array}{c}8470.1 \pm \\
374.0 \\
\end{array}$ & 0.54 \\
\hline 23-25 yrs. & 10 & $\begin{array}{l}8470.0 \pm \\
279.7 \\
\end{array}$ & $\begin{array}{l}9400.3 \pm \\
278.5 \\
\end{array}$ & $\begin{array}{c}9700.2 \pm \\
387.9 \\
\end{array}$ & 0.33 \\
\hline \multicolumn{6}{|c|}{$\begin{array}{c}\text { Table 1. Total Leucocyte Count of Different Phases of } \\
\text { Menstrual Cycle in Relation to Age Groups }\end{array}$} \\
\hline \multicolumn{6}{|c|}{$\begin{array}{l}\text { Note: All data are expressed as mean } \pm \text { SEM, } \mathrm{P}<0.05 \\
\text { (considered statistically significant). }\end{array}$} \\
\hline
\end{tabular}

\begin{tabular}{|c|c|c|c|c|c|}
\hline 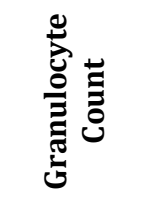 & 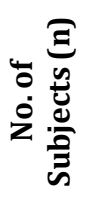 & 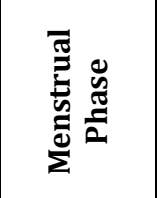 & 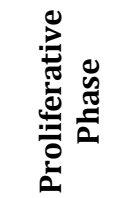 & 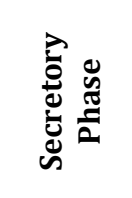 & $\begin{array}{l}\stackrel{0}{\Xi} \\
\stackrel{\pi}{2} \\
\dot{2}\end{array}$ \\
\hline Age group & & & & & \\
\hline $17-19$ yrs. & 26 & $\begin{array}{c}3796.9 \pm \\
379.2\end{array}$ & $\begin{array}{c}3855.1 \pm \\
252.5\end{array}$ & $\begin{array}{c}6457.7 \pm \\
263.8\end{array}$ & .000 \\
\hline $20-22$ yrs. & 14 & $\begin{array}{c}4608.50 \pm \\
699.2\end{array}$ & $\begin{array}{c}4366.9 \pm \\
675.0\end{array}$ & $\begin{array}{c}5613.0 \pm \\
262.2\end{array}$ & .288 \\
\hline 23-25 yrs. & 10 & $\begin{array}{c}4439.6 \pm \\
566.0\end{array}$ & $\begin{array}{c}3466.5 \pm \\
308.5\end{array}$ & $\begin{array}{c}6090.1 \pm \\
215.7\end{array}$ & .000 \\
\hline \multicolumn{6}{|c|}{ Agranulocyte } \\
\hline 17-19 yrs. & 26 & \begin{tabular}{|c|}
$2964.04 \pm$ \\
125.9
\end{tabular} & $\begin{array}{c}3032.9 \pm \\
92.6\end{array}$ & $\begin{array}{c}3280.0 \pm \\
130.9\end{array}$ & .144 \\
\hline 20-22 yrs. & 14 & $\begin{array}{c}2988.9 \pm \\
174.1\end{array}$ & $\begin{array}{c}2903.0 \pm \\
161.6\end{array}$ & $\begin{array}{c}3219.0 \pm \\
180.7\end{array}$ & .417 \\
\hline 23-25 yrs. & 10 & $\begin{array}{c}3047.0 \pm \\
147.6\end{array}$ & $\begin{array}{c}3478.7 \pm \\
219.9\end{array}$ & $\begin{array}{l}3168.7 \\
\pm 146.8\end{array}$ & .213 \\
\hline
\end{tabular}

Table 2. Comparison of Granulocyte \& Agranulocyte Count in Different Phases of Menstrual Cycle in Different Age Groups

Note: All data are expressed as mean \pm SEM, $\mathrm{p}<0.05$ (considered statistically significant).

LH surge causes ovulation and during secretory phase causes luteinisation of granulosa cells to secrete progesterone, which helps in the formation and maintenance of corpus luteum. This LH surge is due to increased frequency of GnRH bursts, increased sensitivity of anterior pituitary to GnRH bursts during this period and probably due to increased oestrogen/estriol ratio. It is now recognised that important systemic as well as haematological changes are accompanying the various phases of the menstrual cycle. Repeated cyclical haemorrhages and variations in the oestrogens and progesterone during menstrual cycle may affect the haematological values as well as blood volume. The Physiological level of oestrogen and progesterone influence the leucocytes count. Thus change in the count might occur when the hormonal balance changes during menstrual cycle and most commonly the organs in the body remain unaffected by this hormonal imbalance.[4,5] The naturally occurring fluctuation in the levels of sex steroid hormones during the menstrual cycle provide convenient basis for analysing the interaction between sex steroid hormones and immune mechanism. Both clinical and experimental evidence support the hypothesis that gonadal steroids regulate immune function. The granulocyte and agranulocyte cells in the peripheral blood play an important role in immunity. The physiological stress and hormonal changes during reproductive age may result to change in the blood count.[7,8] The optimal availability of immune cells in the peripheral blood streams of women plays a critical role in their response to disease and therapeutic intervention. Interaction between reproductive and immune system plays an important and immuno regulatory role. Recent clinical studies show that survival rates of women with operable breast cancer varied based on the time of menstrual cycle at operation. Overall and recurrence free survival was greatly reduced in women whose surgery took place 3-12 days after onset of menses, as compared to those operated from day $0-2$ or day $13-32 .(8,15)$ Aged might also play another factor that may influence the increased and decreased in total leucocyte count and granulocyte, agranulocyte count in the body during menstruation and also might be due to hormonal fluctuations occurring in female which is still need further investigations. Therefore, the present study was taken up to determine the aged really influences the total leucocyte count and granulocyte, agranulocyte count during various phases of menstrual cycle which may help in understanding various aged related disorder occurring in female.

\section{Aim of The Study}

The present study was taken up to study the aged related variations in total leucocyte, granulocyte and agranulocyte count during different phases of menstrual cycle in $1^{\text {st }}$ professional MBBS students at Jawaharlal Nehru Institute of Medical sciences (JNIMS), Imphal, Manipur.

\section{METHODS}

It is a longitudinal study. The present study was carried out in 50 healthy female medical students of 1 st year between the aged groups of 18-25 years with normal regular menstrual cycle were universally selected. The duration of the cycle was $28 \pm 2$ days. Subject with irregular cycles, gynaecological disorders like endometriosis, fibroids and with heavy menstrual bleeding, anaemia, history of drug intake affecting menstrual cycle or history of chronic disease and fever at the time of sampling were excluded from the study. Study protocol was explained to the students and informed consent was obtained from each of the student. This study was carried out in accordance to the ethical standards of the committee to Helsinki declaration.[6] Institutional ethical committee clearance was obtained. First sample was collected within 48 hours of onset of menstruation, second sample during days $8^{\text {th }}-10^{\text {th }}$ of menstrual cycle. Third sample was taken during days $22^{\text {nd }}-24^{\text {th }}$ of menstrual cycle. All the subjects were followed up during a single cycle. Samples were taken at morning time at 9am-10am to avoid diurnal variation. Total leucocyte count was made under Improved Neubauer's chamber using Turk's fluid which was examined under compound microscope and their undiluted blood is calculated. The Granulocyte consist of Neutrophils, basophils, eosinophils and agranulocytes i.e. monocytes, lymphocytes were examined by using Leishman's stain under compound microscope. A minimum of 100 WBCs are identified in a 
systematic manner and counting were made by using Tallybar method in the Haematology Laboratory of Department of Physiology, Jawaharlal Nehru Institute of Medical Sciences (JNIMS), Imphal, Manipur. The parameters were statistically analysed by using descriptive statistical i.e., mean and standard deviation. Association between the variables and significant were calculated by using one-way ANOVA. The $p$ value $<0.05$ was considered statistically significant.

\section{RESULTS}

(Table 1) The mean \pm SEM of aged groups of 23-25 years of total leucocytes count was increased in secretory phases as compared to other aged groups of menstrual and proliferative phases of the menstrual cycle but was not statistically significant.

(Table 2) Shows the mean \pm SEM of granulocyte count in menstrual, proliferative and secretory phases of menstrual cycle in different aged groups of 17-19 years, 23-25 years, it shows increased in granulocyte count in all the three phases i.e.- menstrual, proliferative and secretory phases of the menstrual cycle and was found statistically significant ( $\mathrm{P}<0.05$ ) but in the aged groups of $20-22$ years, the granulocyte count was increased in all the three phases i.e.menstrual, proliferative and secretory phase of menstrual cycle but was not statistically significant.

The mean \pm SEM of granulocyte count was increased in the aged groups between 23-25 years in all the phases i.e.menstrual, proliferative and secretory phases of the menstrual cycle as compared with the other aged groups i.e.(17-19 years, 20-22 years) in all the phases of the menstrual cycle but was not statistically insignificant.

\section{DISCUSSION}

Menstruation is a cyclical shedding of endometrium during reproductive age. It is regulated by ovarian steroid hormones namely oestrogen and progesterone, which in turn controlled by an integrated hypothalamo-pituitary ovarian axis through release of FSH and LH. The release of GnRH by hypothalamus is pulsatile, with pulses occurring every 90 mins. This leads to pulsatile release of FSH and LH. Frequency of GnRH bursts is increased by oestrogen and decreased by progesterone. LH surge causes ovulation and during secretory phase causes luteinisation of granulosa cells to secrete progesterone, which helps in the formation and maintenance of corpus luteum. This LH surge is due to increased frequency of GnRH bursts, increased sensitivity of anterior pituitary to GnRH bursts during this period and probably due to increased oestrogen/estriol ratio. The Physiological level of oestrogen and progesterone influence the leucocytes count. Thus change in the count might occur when the hormonal balance changes during menstrual cycle and most commonly the organs in the body remain unaffected by this hormonal imbalance. However, rise in granulocyte, agranulocyte and total leucocyte counts may be due to the release of tremendous number of leucocytes during menstruation.[9] Malipatil BS et al, also observed that there is increased total leucocyte count and granulocyte count in proliferative phase as compared to menstrual and secretory phase in the aged group of 18-23 years but was not statistically significant due to increase in 17 beta Estradiol and also he reported that during menstrual cycle differences in granulocyte, agranulocyte, total leucocyte count are influenced by the diurnal variations as well as monthly hormonal level \& needs further examination. These results identify significant fluctuation in number and patterns of circulating immune cells in women's immune response. The optimal availability of immune cells in peripheral blood streams of women plays a critical role in their response to disease and therapeutic interventions. [12] In comparison of the three different aged groups in different phases of menstrual cycle revealed that there was rise in the total leucocyte count and agranulocytes count of subjects within the aged 23-25 years but was not statistically significant, whereas there was statistically significant increase in granulocyte count in various phases of the menstrual cycle. This implies that subjects between 17 19) (23-25) years of aged are more resistant to infections during menstruation and their body produced a stronger immune system in the form of tremendous number of leucocytes to help attack any form of infections. In vitro studies have suggested that oestrogen enhances granulocyte proliferation. [10] The finding of the present study is in consistent with the finding of Tikare et al., Dixon et al. $[7,11]$ Some authors observed that with the increasing aged in women there was a significant fall in total white cells count due to falling of lymphocytes count and marked fall in polymorph counts. No significant aged related variations are seen in men. In contrast, in the present study showed statistically significant increase of granulocyte count in aged group between (17-19) \& (23-25) years in all phases of menstrual cycle whereas no significant aged related variation of the total leucocytes count could be seen between 20-22 years. Therefore, aged also another factor that may influence the increased in granulocyte count in the body during menstruation and also might be due to hormonal fluctuations occurring in female which is still need further investigations. The physiological stress and hormonal changes during reproductive age may result to change in the blood count. The physiological stress affecting the peripheral blood count may be resulted due to alteration in plasma oestrogen and progesterone during the phases of the cycle.[7,8,13] This variation in cell count may be due to increased $17 \beta-$ E2 concentrations that promotes the release of granulocyte and agranulocyte from the bone marrow.[14]

\section{CONCLUSIONS}

This study shows that there are some changes in total leucocyte count and granulocyte- and agranulocyte-count in different age groups during different phases i.e.-menstrual, proliferative and secretory phases of menstrual cycle and the aged related variations of blood count may be due to physiological stress and hormonal changes occurring during reproductive aged. These hormonal changes may influence the availability of immune cells in the peripheral blood. Numerous studies have been conducted to study the immune system changes in the reproductive life but still it is contradictory and inconclusive. This study gives the knowledge about the age-related immune cells availability which may help in understanding the various autoimmune diseases like rheumatoid arthritis, systemic lupus erythematosus, autoimmune thyroid disease, multiple sclerosis etc. occurring in reproductive age groups. There is a need for further studies with larger sample to confirm the 
results and to understand the changes in leucocytes affecting the females in reproductive age.

\section{ACKNOWLEDGEMENT}

The authors wish to thank the Director of Jawaharlal Nehru Institute of Medical Sciences (JNIMS), Imphal, Manipur and the Head, Department of Physiology, Jawaharlal Nehru Institute of Medical Sciences (JNIMS), Imphal, Manipur, for their help. We are also thankful to the staff of departments of haematology, physiology. We also want to thank the $1^{\text {st }}$ year medical students for their kind co-operation.

\section{REFERENCES}

[1] Khurana I. Female Reproductive Physiology. In: Jha AK, Pant NC, eds. Textbook of Physiology. $1^{\text {st }}$ edn. New Delhi: Elsevier Saunders 2010: p. 866.

[2] Kumar P, Malholtra N. Menstruation and other cyclical phenomenon. In: Vij JP, edr. Jeffcott's principles of Gynecology. $7^{\text {th }}$ edn. New Delhi: Jaypee Brothers 2008: p. 80-7.

[3] Rajan P, Rao GS, Walter S. Blood basopenia as an indicator of ovulation. Indian J Physiology Pharmacol 1992;36(2):115-7.

[4] Rajnee, Chawla VK, Choudhary R, et al. Haematological and electrocardiographic variations during menstrual cycle. Pak J Physiol 2010;6(1):18-21.

[5] Speroff L, Vande Wiele RL. Regulations of the human menstrual cycle. Am J Obset Gynae 1971;109(2):23447.

[6] Declaration of Helsinki (1964), 1996. Amended by World Medical Assembly, Venice, Italy. Br Med J 1983;313:1448-9.
[7] Guyton AC, Hall JE. Resistance of the body to infection. In: Schmitt W, Gruliow R, eds. Textbook of Physiology. $12^{\text {th }}$ edn. Philadelphia: Elsevier Saunders 2011: p. 42335.

[8] Northern AL, Rutter SM, Peterson CM. Cyclic changes in the concentrations of peripheral blood immune cells during the normal menstrual cycle. Physiological Society of Experimental Biology and Medicine 1994;207(1):81-8.

[9] Bain B, Seed M, Godsland I. Normal values for peripheral blood cell counts in women of four different ethnic origins. J Clin Pathol 1984;37(2):18893.

[10] Tikare SN, Das KK, Dhundasi SA. Blood leukocyte profile in difference phases in menstrual cycle. Indian J Physiol Pharmacol 2008;52(2):201-4.

[11] Malipatil BS, Patil S. Hematological modulation in different phases of menstrual cycle. IJBR 2013;4(2):88-92.

[12] Mehrotra HN, Pant MC, Tandon GK, et al. A study of certain haematological and metabolic changes during preovulatory period. Indian J Physiol Pharmacol 1978;22(2):188.

[13] Agoreyo FO, Asowata EO. Assessment of total leukocytes during menstruation. Int $\mathrm{J}$ of Med and Medical Sciences 2011;3(1):19-21.

[14] Bain BJ, England JM. Variations in leucocyte count during menstrual cycle. BMJ 1975;2(5969):473-5.

[15] Pepper H, Lindsay S. Levels of platelets, eosinophils, total leucocytes and polymorphonuclear leucocytes during the normal menstrual cycle. Obstetrics and Gynecology 1959;14(5):657-64. 